\title{
THE MANAGEMENT OF CONGENITAL DIAPHRAGMATIC HERNIA
}

\author{
R. E. Cheighton, M.D., F.R.C.P.(C), J. S. Whalen, M.D., F.A.A.P., \\ AND A. W. CoNN, M.D., B.SC.(MED.), F.R.C.P.(C)
}

CongentTal DIAPHRAgmatic hERNIA occurs infrequently. The exact incidence is unknown. However, a 1961 study of deaths in the newborn period showing major congenital anomalies revealed an 8.5 per cent incidence of congenital diaphragmatic hernia. Therefore, it may present an acute emergency in the newborn period.

\section{Classiftcation of Diaphragmatic Hernia}

1. Posterolateral defects in the diaphragm through the foramen of Bochdalek.

2. Retrosternal or retrocostosternal defects in the diaphragm through the foramen of Morgagni.

3. Anterolateral defects in the diaphragm.

4. Eventration.

5. Oesophageal hiatus hernia.

\section{Diagnosis}

The usual findings on examination of these patients are (a) dyspnoea, often severe and associated with cyanosis; (b) decreased or absent breath sounds on the involved side, and (c) a shift of the mediastinum and its contents to the contralateral side. Auscultation for peristalis over the involved hemithorax is unreliable.

Diagnosis is confirmed on chest X-ray, where the congenital lung cysts are the principal differential diagnosis. Contrast medium is rarely required.

During the five-year period from January 1959 to December 1964, 21 newborn infants were operated upon for diaphragmatic hernia under emergency conditions at the Hospital for Sick Children in Toronto within the first 30 hours of life. Of these, 16, or 76.2 per cent, survived. All the fatal cases and 50 per cent of the survivors were operated upon within 10 hours of birth.

The weights of the survivors ranged from 2.5 to $3.4 \mathrm{~kg}$. with an average of 3.2 $\mathrm{kg}$. Only three weighed less than $3.0 \mathrm{~kg}$. The weights of those who did not survive ranged from 1.7 to $3.0 \mathrm{~kg}$. with an average of $2.5 \mathrm{~kg}$.

\section{Preoperative Condrtion}

All surviving patients showed some degree of respiratory distress while five (31.3\%) showed severe respiratory distress with marked cyanosis. All those who

-Department of Anaesthesia, Hospital for Sick Children, Toronto. 
CREIGHTON, et al.: MANAGEMENT OF CONGENITAL DIAPHRAGMATIC HERNIA 125

succumbed showed cyanosis, and four of five (80\%) were considered to be in severe respiratory distress.

\section{Pheoperative Management}

In most cases, pre-operative management consisted of investigation including physical examination, haemoglobin, and chest X-ray. Occasionally, barium meal was performed.

An intravenous cut-down was started at the ankle, cross-match for whole blood performed, and the patient placed in a croupette with a high-humidity, oxygenenriched atmosphere. On some occasions it was necessary to intubate the patients awake and assist or control respiration.

\section{Anaesthetic Management}

The patients received atropine sulphate 0.1 to $0.15 \mathrm{mg}$. Some were intubated prior to operation. A total of 14 (including all the five fatalities) were intubated awake. Four patients were intubated after intravenous succinylcholine alone (2 mg./kg.) while three were intubated after a gaseous induction without relaxant.

\section{Maintenance Anaesthesia}

In all cases, respiration was controlled with some degree of hyperventilation. Only one diaphragmatic hernia was right-sided. The majority of left-sided diaphragmatic herniae occurred through the foramen of Bochdalek. In all cases, an abdominal surgical approach was used.

Among those patients who survived, the average duration of anaesthesia was 94 minutes, with a range of 75 to 120 minutes. Among those who succumbed, the average duration of anaesthesia was 136 minutes, with a range of 110 to 180 minutes.

The average length of stay in hospital for the survivors was 15.8 days, and the range was 10 to 28 days.

\section{Postoperative Complicattons}

\section{A. Survivors}

1. One patient suffered from postoperative vomiting and remained in hospital for 28 days. A recurrence of the hernia was diagnosed at 18 months and repaired.

2. One patient was re-admitted and operated upon at 6 months for bowel obstruction.

3. One patient developed a pneumothorax on the right side (contralateral) postoperatively. A needle puncture was performed and $50 \mathrm{ml}$. of air was withdrawn.

4. One patient exhibited respiratory distress for several days with a large left (ipsilateral) pneumothorax which eventually cleared without drainage. The patient was discharged after 16 days. 
5. One patient developed gastroenteritis which cleared and was discharged after 17 days.

In only two cases was a chest drain left in the thorax in the immediate postoperative period.

\section{B. Fatal Cases}

1. A $2.8 \mathrm{~kg}$. male child presented marked respiratory distress and cyanosis. He was intubated awake and the hernia was repaired $6 \%$ hours after birth under $\mathrm{N}_{2} \mathrm{O}-\mathrm{O}_{2}$ and succinylcholine. However, due to continued respiratory distress and copious secretions in the respiratory tree the endotracheal tube was left in place for aspiration and controlled ventilation. After 22 hours, the tube was removed but respiratory distress was so severe it was re-inserted and the child continued on controlled ventilation for three days, until death. Autopsy revealed atelectasis of the left lung, bilateral haemorrhagic effusions, and acute bronchopneumonia with small brain abscesses.

2. A $2.3 \mathrm{~kg}$. male child was in such respiratory distress on admission that he was intubated in the emergency department and operated upon 4 $1 \frac{1}{2}$ hours after birth under $\mathrm{O}_{2}$ and succinylcholine and minimal ether. At the time of operation, the hernia was found to be too large to be completely closed. The child had several episodes of cyanosis postoperatively, and at 18 hours was intubated to assist laboured breathing. At this time, $45 \mathrm{ml}$. of blood was removed from the left thorax and an indwelling catheter left in place. However, the child died one day postoperatively. Autopsy revealed a diaphragmatic tear subsequent to the repair, and congestive heart failure.

3. A $2.7 \mathrm{~kg}$, male child was brought to us in severe respiratory distress and a state of circulatory collapse. He was intubated awake and operated upon $5^{1 / 2}$ hours after birth under $\mathrm{O}_{2}$ and succinylcholine. During the operation he sustained a cardiac arrest and was resuscitated with massage, epinephrine, and calcium. Surgery was terminated with the defect incompletely closed. The child was maintained on controlled ventilation via an endotracheal tube with bilateral chest drains. However, he never regained an adequate blood pressure and died three hours postoperatively. There was no consent for autopsy.

4. A $1.7 \mathrm{~kg}$. premature female child was in such distress that she suffered a cardiac arrest shortly after admission to the emergency department. It was necessary to make an emergency incision and remove abdominal viscera from the chest as a life-saving measure. This child was resuscitated, taken to the operating room and the repair performed 3\% hours after birth. Acidosis was corrected with $\mathrm{NaHCO}_{3}$. Postoperatively, the child was placed on controlled ventilation via an endotracheal tube, but died five hours after operation. There was no consent for autopsy.

5. A $3.0 \mathrm{~kg}$. female child was in severe respiratory distress with cyanosis. Venous pH was 7.14. The child was intubated awake and given $\mathrm{NaHCO}_{3}$, and the hernia was repaired under $\mathrm{N}_{2} \mathrm{O}-\mathrm{O}_{2}$-ether and succinylcholine. However, four days postoperatively the child developed respiratory failure with copious respiratory secretions, heart failure, and metabolic acidosis as well as ulcerative stomatitis. She died six days postoperatively, after two successful resuscitations 
CREIGHTON, et al.: MANAGEMENT OF CONGENITAL DIAPERAGMATIC HERNIA 127

from cardiac arrest. There was no consent for autopsy. A generalized herpetic infection was postulated as one of the possible causes of death.

Rocommendations for Management of Congenttal Diaphragmatic Herna

\section{A. Immediate upon Admission}

1. Insertion of catheter into stomach with constant suction until operation.

2. Semi-upright position lying toward the involved side.

3. Isolette with humidified oxygen-enriched atmosphere.

4. Awake intubation with or without assisted or controlled ventilation, if required.

5. Astrup capillary blood studies for acid-base disturbances with appropriate therapy, i.e. ventilation, $\mathrm{NaHCO}_{3}$, or $0.6 \mathrm{M}$. THAM.

6. Intravenous cutdown.

7. Cross match for whole blood ( $250 \mathrm{ml}$.).

\section{B. Operative Management}

1. Premedication: Atropine sulphate $0.1-0.15 \mathrm{mg}$.

2. Induction:

One hundred per cent oxygen inhalation for several minutes followed by awake intubation is recommended.

Oxygen under pressure with a face mask is contraindicated, since it will cause further distention of the abdominal viscera in the thorax.

Succinylcholine should not be used to facilitate intubation. It would prove dangerous if any difficulty occurred while establishing control of the airway.

Endotracheal tube connectors should be of the plug and chain type, to allow direct connection to a pressure manometer. Twenty-five to thirty $\mathrm{cm}$. of $\mathrm{H}_{2} \mathrm{O}$ should be the maximum allowable endotracheal pressure. Vigorous attempts should not be made to expand the ipsilateral lung. Rupture of lung alveoli and subsequent pneumothorax may occur.

3. Maintenance:

Severely ill patients should be managed with 100 per cent oxygen and intermittent, dilute $(2 \mathrm{mg} . / \mathrm{c.c}$.) succinylcholine.

Nitrous oxide may be added to the above mixture in the less seriously ill patients.

Halothane 0.5 per cent may also be required in the robust patients who would otherwise require a fairly large total dose of succinylcholine.

Intermittent dilute succinylcholine is preferred to d-tubocurare. Its short action allows for titration against the needs of the patient and it may be stopped at any time to assess the disability during spontaneous respiration.

\section{Postoperative Management}

At the termination of surgery, three courses of action are available depending on the degree of respiratory disability.

1. The endotracheal tube may be removed if respiration is satisfactory and the patient returned to his isolette.

2. The endotracheal tube may be left in or replaced by a nasotracheal tube in patients who show mild to moderate respiratory difficulty. This will facilitate 
removal of bronchial secretions and assisted or controlled ventilation, if required, at a later time. The patient must be kept in a high humidity atmosphere, e.g., that supplied by an ultrasonic nebulizer.

3. The patients exhibiting serious respiratory distress should have a nasotracheal tube inserted. Ventilation should be assisted or controlled. Adequate nebulization and suctioning is essential. Further respiratory and acid-base management will be predicted by several Astrup capillary blood studies. Additional postoperative therapy includes $(a)$ postoperative gastric suction drainage and intravenous fluids until distention subsides; $(b)$ gavage feedings on the second or third postoperative day; (c) blood transfusion as required; $(d)$ serial $\mathrm{X}$-rays to determine the expansion of the ipsilateral lung.

\section{Rúsumé}

On ne connait pas exactement la fréquence de la hernie diaphragmatique congénitale, mais elle peut se présenter comme un cas d'extrême urgence chez le nouveau-né. De 1959 à 1964, à l' "Hospital for Sick Children" de Toronto, on a opéré d'urgence vingt-et-un nouveaux-nés durant les trente premières heures de leur vie. De ce nombre, seize ont survécu, soit 76.2 pour cent. Les auteurs ont passé en revue l'état pré-opératoire, et le traitement des survivants et des autres; ils ont décrit l'évolution clinique et les résultats d'autopsies qu'ils ont pu obtenir. On fait les recommandations suivantes pour le traitement de la hernie diaphragmatique congénitale:

\section{A. Dès ladmission}

1. Installation d'un cathéter dans l'estomac et succion continue jusqu'à l'opération.

2. Position de Fowler, le malade couché sur le côté touché.

3. "Isolette" où l'atmosphère est riche en oxygène et humidifié.

4. Intubation sans anesthésie, suivie ou non de ventilation assistée ou contrólée selon les indications.

5. Etudes du sang capillaire pour déceler les déséquilibres acide-base et traitement approprié, c'est-à-dire, ventilation, $\mathrm{NaHCO}_{3}$ ou $0.6 \mathrm{M}$. THAM.

6. Dissection veineuse.

7. Groupe sanguin en vue d'une transfusion de 250 c.c. de sang complet.

\section{B. Opération}

1. Prémédication-Sulfate d'atropine 0.1 à $0.15 \mathrm{mgm}$.

2. Induction.

$100 \%$ d'oxygène durant plusieurs minutes puis intubation à l'état de veille.

Il est contrindiqué d'administrer de l'oxygène sous pression a l'aide d'un masque facial, puisqu'il s'ensuivrait une plus grande distension des viscères abdominaux dans le thorax.

Il ne faut pas utiliser la Succinylcholine pour faciliter l'intubation. Cette mesure serait dangereuse si quelque difficulté survenait durant les tentatives d'établir une bonne respiration contrólée. 
CRETGHTON, et al.: MANAGEMENT OF CONGENTTAL DIAPHRAGMATIC HERNIA 129

Les joints du tube endotrachéal devraient être d'un genre qui permet facilement le raccordement d̀ un manomètre. Il ne faut pas dépasser 25 à 30 centimètres d'eau de pression endotrachéale. Il faut éviter les efforts pour provoquer l'expansion du poumon du côté opéré. On pourrait rupturer les alvéoles et provoquer un pneumothorax subséquent.

3. Entretien.

Les grands malades ne devraient recevoir que $100 \%$ d'oxygène et de façon intermittente, de la succinylcholine diluée ( 2 milligrammes par c.c.).

On peut ajouter du protoxyde d'azote chez les malades moins touchés.

On peut avoir à administrer de l'Halothane ( $0.5 \%)$ chez les malades robustes qui autrement exigeraient de fortes doses de succinylcholine.

Il vaut mieux utiliser de façon intermittente la succinylcholine diluée plutôt que la d-tubocurarine. Son action brève permet de mieux doser selon les besoins du malade et on peut cesser de l'administrer à tout moment pour évaluer l'incapacité au cours de la respiration spontanée.

\section{Soins postopératoires}

A la fin de l'opération, on peut suivre l'une des trois lignes de conduite suivantes selon le degré d'insuffisance respiratoire:

1. Si la respiration est suffisante, on peut extuber le malade et le retourner à son "isolette".

2. On peut laisser le tube oro-trachéal ou le remplacer par un tube nasotrachéal chez les malades qui présentent des troubles respiratoires légers ou modérés. Ceci facilitera l'aspiration des sécrétions bronchiques et la ventilation assistée ou contrôlée, si elle devient nécessaire plus tard. On doit garder le malade dans une atmosphère à l'humidité élevée, telle qu'on peut l'obtenir à l'aide d'un nébulisateur ultrasonique.

3. Il faut pratiquer une intubation naso-trachéale chez les malades qui présentent une détresse respiratoire sérieuse. Il faut assister ou contrôler la ventilation. Il est essentiel de vaporiser suffisamment et d'aspirer. La ligne de conduite subséquente au point de vue respiratoire et équilibre acide-base sera guidée par des analyses de sang répétées. Parmi les autres soins post-opératoires, il faut noter: (a) succion continue de l'estomac et liquides intraveineux tant que persiste la distension; (b) alimentation par gavage à partir du $2^{\mathrm{e}}$ ou $3^{\mathrm{e}}$ jour après l'opération; (c) transfusions au besoin; $(d)$ radiographies répétées pour déterminer l'expansion du poumon du côté de l'opération. 